Research Report

\title{
Sh-I-048A, an in vitro non-selective super-agonist at the benzodiazepine site of GABAA receptors: The approximated activation of receptor subtypes may explain behavioral effects
}

\author{
Aleksandar Lj. Obradovića , Srđan Joksimovićb ${ }^{b}$ Michael M. Poe $e^{c}$,

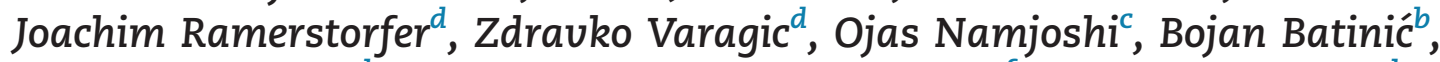 \\ Tamara Radulović ${ }^{b}$, Bojan Markoviće, Brian L. Roth ${ }^{f, g}$, Werner Sieghart ${ }^{d}$, \\ James M. Cook ${ }^{c}$, Miroslav M. Savićb,* \\ ${ }^{a}$ Department of Physiology, Faculty of Pharmacy, University of Belgrade, Vojuode Stepe 450, 11221 Belgrade, Serbia \\ bDepartment of Pharmacology, Faculty of Pharmacy, University of Belgrade, Vojuode Stepe 450, 11221 Belgrade, Serbia \\ ${ }^{\mathrm{C} D e p a r t m e n t}$ of Chemistry and Biochemistry, University of Wisconsin - Milwaukee, P.O. Box 413, Milwaukee, \\ WI 53201, USA \\ ${ }^{\mathrm{d} D e p a r t m e n t}$ of Biochemistry and Molecular Biology, Center for Brain Research, Medical University Vienna, \\ Vienna, Austria \\ e Department of Pharmaceutical Chemistry, Faculty of Pharmacy, University of Belgrade, Vojuode Stepe 450, 11221 \\ Belgrade, Serbia \\ f Department of Pharmacology, University of North Carolina Chapel Hill Medical School, Chapel Hill, NC 27514, USA \\ gDivision of Chemical Biology and Medicinal Chemistry, University of North Carolina Chapel Hill Medical School, Chapel \\ Hill, NC 27514, USA
}

\section{A R T I C L E I N F O}

Article history:

Accepted 20 January 2014

Available online 25 January 2014

Keywords:

Equilibrium dialysis

Free brain concentration

Diazepam

Rat

\begin{abstract}
A B S T R A C T
Enormous progress in understanding the role of four populations of benzodiazepinesensitive $G_{A B A}$ receptors was paralleled by the puzzling findings suggesting that substantial separation of behavioral effects may be accomplished by apparently nonselective modulators. We report on SH-I-048A, a newly synthesized chiral positive modulator of $\mathrm{GABA}_{\mathrm{A}}$ receptors characterized by exceptional subnanomolar affinity, high efficacy and non-selectivity. Its influence on behavior was assessed in Wistar rats and contrasted to that obtained with $2 \mathrm{mg} / \mathrm{kg}$ diazepam. SH-I-048A reached micromolar concentrations in brain tissue, while the unbound fraction in brain homogenate was around $1.5 \%$. The approximated electrophysiological responses, which estimated free concentrations of SH-I-048A or diazepam are able to elicit, suggested a similarity between the $10 \mathrm{mg} / \mathrm{kg}$ dose of the novel ligand and $2 \mathrm{mg} / \mathrm{kg}$ diazepam; however, SH-I-048A was relatively more active at $\alpha_{1}$ - and $\alpha_{5}$-containing GABA receptors. Behaviorally, SH-I-048A induced sedative, muscle relaxant and ataxic effects, reversed mechanical hyperalgesia $24 \mathrm{~h}$ after injury, while it was devoid of clear anxiolytic actions and did not affect watermaze performance. While lack of clear anxiolytic actions may be connected with an
\end{abstract}

\footnotetext{
*Corresponding author. Fax: +381 113972840.

E-mail address: miroslav@pharmacy.bg.ac.rs (M.M. Savić).
} 
enhanced potentiation at $\alpha_{1}$-containing $\mathrm{GABA}_{\mathrm{A}}$ receptors, the observed behavior in the rotarod, water maze and peripheral nerve injury tests was possibly affected by its prominent action at receptors containing the $\alpha_{5}$ subunit. The current results encourage further innovative approaches aimed at linking in vitro and in vivo data in order to help define fine-tuning mechanisms at four sensitive receptor populations that underlie subtle differences in behavioral profiles of benzodiazepine site ligands.

(c) 2014 Elsevier B.V. All rights reserved.

\section{Introduction}

Ionotropic receptors for the inhibitory neurotransmitter $\gamma$-aminobutyric acid (GABA) are the most widely distributed receptors in the central nervous system (Watanabe et al., 2002) and at the same time successfully exploited drug targets (Sieghart, 2006). Among drugs acting through $\mathrm{GABA}_{\mathrm{A}}$ receptors, benzodiazepines (BZs) have been established as especially versatile GABA-modulatory drugs. However, a plethora of regulatory roles of GABA itself is reflected in a wide range of pharmacological actions of BZs and an increased burden of side effects. The recognition that the molecular substrate of $\mathrm{BZ}$ action comprises four populations of $\mathrm{GABA}_{\mathrm{A}}$ receptors which contain the $\alpha_{1}, \alpha_{2}, \alpha_{3}$ or $\alpha_{5}$ subunit, in addition to the $\gamma_{2}$ subunit, has given an impetus for synthesis and development of newer ligands. It was hypothesized that four populations of BZsensitive $G_{A B A}$ receptors mediate distinct sets of behavioral responses, enabling separation of desirable effects mediated by one, from undesirable effects supposedly mediated by the other subtype of receptors (Olsen and Sieghart, 2008; Rudolph and Möhler, 2006).

A number of subtype selective ligands acting at the BZ site have been reported in recent years, with the final aim of obtaining the optimal balance between efficacy and safety and possibly broadening the current spectrum of indications (Rudolph and Knoflach, 2011). This concept pursued the results of genetic studies, which have attributed the sedative and ataxic properties of BZs to the predominantly expressed $\alpha_{1}$ subunit-containing $\mathrm{GABA}_{\mathrm{A}}$ receptors, the anxiolytic, muscle relaxant and antihyperalgesic actions to the $\alpha_{2} / \alpha_{3}$ subtypecontaining receptors, and anticonvulsant activity to all, the $\alpha_{1} / \alpha_{2} / \alpha_{3}$ GABA $_{\mathrm{A}}$ receptors (reviewed in Rudolph and Möhler, 2006). Despite promising preclinical data, no clear clinical breakthroughs have been made to date (Atack et al., 2011) and, indeed, the whole concept has been questioned to a certain degree (Skolnick, 2012). Especially puzzling were the results suggesting that substantial improvement in the behavioral profile may be accomplished by non-selective ligands active at all four populations of $\mathrm{BZ}$-sensitive $\mathrm{GABA}_{\mathrm{A}}$ receptors (Auta et al., 2010; Rabe et al., 2007), or even predominantly active at $\mathrm{GABA}_{\mathrm{A}}$ receptors containing the $\alpha_{1}$ subunit (Lippa et al., 2005; Popik et al., 2006). Such findings were clearly at odds with results from genetic studies showing that sedation and motor impairments exerted by BZs depend to a high degree on positive modulation of $\alpha_{1} G_{A B A}$ receptors (Atack, 2010). The predominantly, though not exclusively hippocampus-based $\alpha_{5}$ $\mathrm{GABA}_{\mathrm{A}}$ receptors are thought to contribute to amnesic effects of BZs (Rudolph and Möhler, 2006), but their biological role is also the subject of debate, because a number of results suggest that activation of these receptors may facilitate memory processing (Koh et al., 2013; McEown and Treit, 2013), as well as reduce psychotic symptoms (Gill et al., 2011).

To tackle the problem in a stepwise way, we hereby report on a newly synthesized chiral positive modulator of $\mathrm{GABA}_{\mathrm{A}}$ receptors characterized by high affinity, high efficacy and nonselectivity, which was examined for its brain exposure and pharmacodynamic profile in rats. In order to estimate pharmacologically active drug concentrations, we calculated the unbound concentrations in brain (Hammarlund-Udenaes, 2010; Read and Braggio, 2010). In vitro and in vivo properties, as well as brain exposure of SH-I-048A were directly compared with data generated, under identical experimental conditions, for the standard non-selective BZ site positive modulator, diazepam. The chosen battery of behavioral tests included those assessing motor status of the animal (spontaneous locomotor activity, rotarod, and grip strength), its anxiety level (open field and elevated plus maze), learning and memory capability (Morris water maze) and pain susceptibility (model of peripheral nerve injury). We hypothesized that a ligand with an in vitro/ex vivo profile demonstrating superiority or, at least, non-inferiority to diazepam, in terms of availability at the receptor site and its subsequent modulation, should exert a set of in vivo actions comparable to those repeatedly reported for diazepam (Rudolph and Knoflach, 2011). Potential failures to support the hypothesis would prove that assigning various behavioral effects to any of specific $G_{A B A}$ receptor populations demands further refining and obtaining more comprehensive experimental data than usually presented (cf. Skolnick, 2012).

\section{Results}

\subsection{In vitro affinity}

The in vitro binding data for SH-I-048A, in parallel with those for diazepam, are presented in Table 1. The novel ligand showed

Table 1 - Binding affinity (Ki, nM) of SH-I-048A and

diazepam at human recombinant $\mathbf{G A B A}_{\mathrm{A}}$ receptors con-

taining $\beta_{3}, \gamma_{2}$ and named $\alpha$ subunit, stably expressed in mouse fibroblast L(tk-) cells; ND - not detected. [ $\left.{ }^{3} \mathrm{H}\right]$ flunitrazepam was used as the radiolabelled ligand in the competition binding assay. Data for diazepam were published in Savis et al. (2010).

\begin{tabular}{lcccccc} 
Ligand & $\alpha_{1}$ & $\alpha_{2}$ & $\alpha_{3}$ & $\alpha_{4}$ & $\alpha_{5}$ & $\alpha_{6}$ \\
\hline $\begin{array}{l}\text { SH-I- } \\
\text { O48A }\end{array}$ & 0.77 & 0.17 & 0.38 & ND & 0.11 & ND \\
Diazepam & 14.0 & 7.8 & 13.9 & ND & 13.4 & ND \\
\hline
\end{tabular}


very high (subnanomolar) affinity for BZ-sensitive recombinant human $\mathrm{GABA}_{\mathrm{A}}$ receptors, considerably higher than that of diazepam. Furthermore, no major selectivity in binding at one over the other subtype was noticed (quite similar to diazepam).

\subsection{Electrophysiological experiments}

Electrophysiological behavior of SH-I-048A and the reference benzodiazepine diazepam in a wide range of concentrations $(1 \mathrm{nM}-10 \mu \mathrm{M})$ is presented in Fig. 1. The novel ligand exerted higher positive modulation than diazepam at all four rat recombinant $\mathrm{GABA}_{\mathrm{A}}$ receptor subtypes. In addition, it seemed to interact with a second binding site at concentrations $>1 \mu \mathrm{M}$, as indicated by the mathematical fit of the data points by a biphasic dose-response simulation using GraphPad Prism. EC $\mathrm{C}_{50}$ values used by this program for fitting the SH-I-048A data were
$14 \mathrm{nM}$ and $2560 \mathrm{nM} ; 14 \mathrm{nM}$ and $1410 \mathrm{nM} ; 20 \mathrm{nM}$ and $2830 \mathrm{nM}$; or $12 \mathrm{nM}$ and $2670 \mathrm{nM}$, for $\alpha_{1} \beta_{3} \gamma_{2}, \alpha_{2} \beta_{3} \gamma_{2}, \alpha_{3} \beta_{3} \gamma_{2}$, or $\alpha_{5} \beta_{3} \gamma_{2}$ containing receptors, respectively. Although an interesting finding, we did not further investigate this low potency interaction of SH-I-048A because the high free concentrations of the ligand required to generate relevant effects via this second site (probably well above $100 \mathrm{nM}$ ) were not reached under the conditions used (see Section 2.3.1) and thus could not have contributed to the results of the present study.

\subsection{Estimation of free plasma and brain concentrations}

\subsubsection{Quantification in rat plasma and brain tissue}

The concentrations of SH-I-048A in rat plasma (nmol/L) and brain tissue $(\mathrm{nmol} / \mathrm{kg})$, both total and free (estimated), are shown in Table 2. Free concentrations of SH-I-048A were

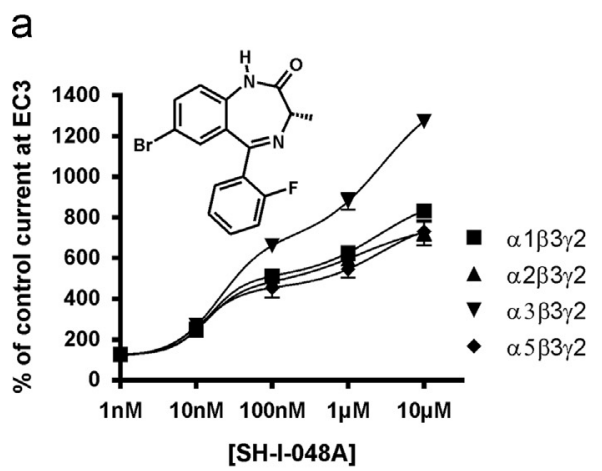

$\alpha 1 \beta 3 \gamma 2$

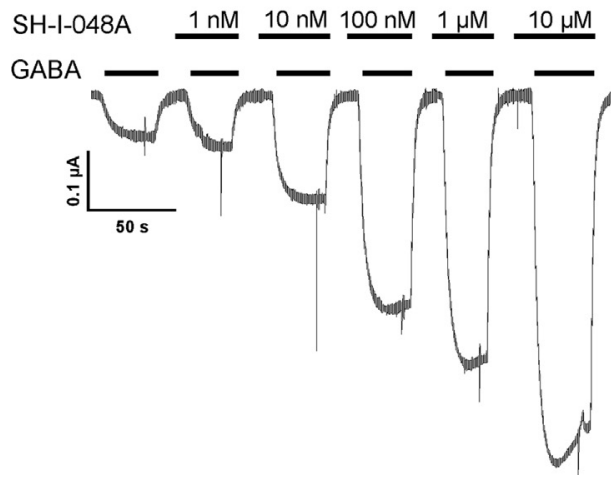

b

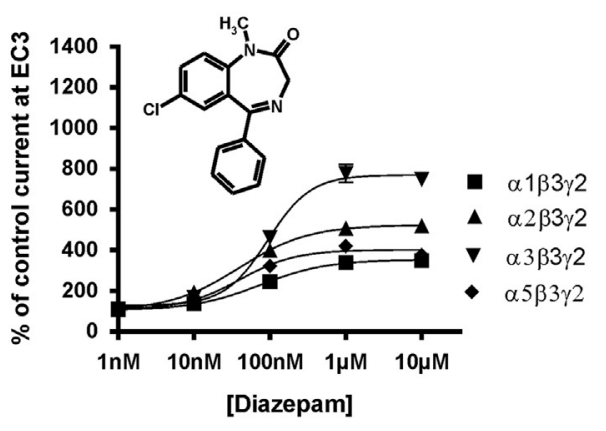

$\alpha 1 \beta 3 \gamma 2$

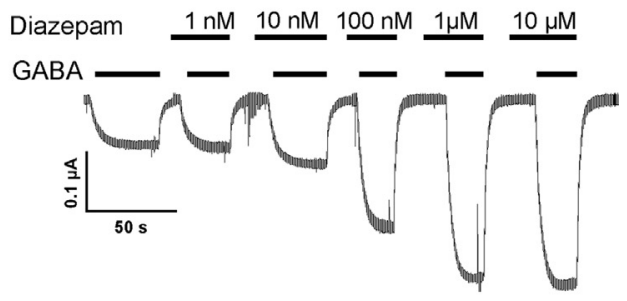

Fig. 1 - Effects of SH-I-048A and diazepam at different GABAA receptor subtypes. (a) Concentration-response curves of SH-I-

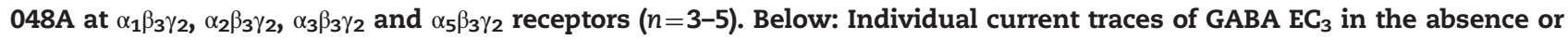
presence of increasing SH-I-048A concentrations at $\alpha_{1} \beta_{3} \gamma_{2}$ receptors. (b) Concentration-response curves of diazepam at $\alpha_{1} \beta_{3} \gamma_{2}$, $\alpha_{2} \beta_{3} \gamma_{2}, \alpha_{3} \beta_{3} \gamma_{2}$ and $\alpha_{5} \beta_{3} \gamma_{2}$ receptors ( $\left.n=5-9\right)$. Below: Individual current traces of GABA EC $\mathrm{C}_{3}$ in the absence or presence of increasing diazepam concentrations at $\alpha_{1} \beta_{3} \gamma_{2}$ receptors. Data are mean values \pm SEM.

Table 2 - Total and estimated free concentrations of SH-I-048A (dosed at 0.5, 2 and $10 \mathrm{mg} / \mathrm{kg}$ ) in plasma and brain samples after 20 and $60 \mathrm{~min}$.

\begin{tabular}{|c|c|c|c|c|c|c|}
\hline \multirow{2}{*}{$\begin{array}{l}\text { Dose (mg/kg) } \\
\text { Time (min) }\end{array}$} & & \multirow{2}{*}{$\begin{array}{l}0.5 \\
20\end{array}$} & \multicolumn{2}{|l|}{2} & \multicolumn{2}{|l|}{10} \\
\hline & & & 20 & 60 & 20 & 60 \\
\hline \multirow[t]{2}{*}{ Plasma (nmol/L) } & Total & $187.59 \pm 26.66$ & $818.82 \pm 57.06$ & $617.87 \pm 149.35$ & $1591.41 \pm 5.15$ & $1396.19 \pm 492.70$ \\
\hline & Free & 8.43 & 36.79 & 27.76 & 71.50 & 62.73 \\
\hline \multirow[t]{2}{*}{ Brain (nmol/kg) } & Total & $231.12 \pm 52.27$ & $750.59 \pm 307.14$ & $739.37 \pm 182.94$ & $2096.33 \pm 858.32$ & $1035.23 \pm 421.19$ \\
\hline & Free & 3.26 & 10.60 & 10.45 & 29.62 & 14.63 \\
\hline
\end{tabular}


calculated by multiplying the measured total plasma and brain concentrations with the appropriate estimated free fractions.

\subsubsection{Plasma protein and brain tissue binding studies}

Free fractions of SH-I-048A in rat plasma and brain tissue determined by rapid equilibrium dialysis were $4.49 \%$ and $1.41 \%$, respectively.

\subsubsection{Assessment of in vivo efficacy}

The exact in vitro efficacy values for SH-I-048A and diazepam at each of four recombinant $\mathrm{GABA}_{\mathrm{A}}$ receptor subtypes, used for the mathematical fit presented in Fig. 2, were applied to calculate linear equations between two concentrations adjacent to the estimated in vivo free brain concentrations, which are presented in Table 2 for SH-I-048A, while the estimated free concentration of $2 \mathrm{mg} / \mathrm{kg}$ diazepam equals $58.46 \mathrm{nmol} / \mathrm{kg}$ (Savić et al., unpublished data). For example, in vitro efficacies of SH-I$048 \mathrm{~A}$ at $\alpha_{1} \beta_{3} \gamma_{2}$ receptors are $124 \%$ and $256 \%$, for concentrations of $1 \mathrm{nM}$ and $10 \mathrm{nM}$, respectively, giving rise to potentiation of $157 \%$ when in vivo free concentration of $3.26 \mathrm{nM}$ was applied to the corresponding linear equation; the values calculated by this approach are presented in Fig. 7.

\subsection{Behavioral experiments}

\subsubsection{Spontaneous locomotor activity}

The influence of SH-I-048A (dosed at 2, 5 and $10 \mathrm{mg} / \mathrm{kg}$ ) on the total distance traveled during $30 \mathrm{~min}$ of monitoring did not reach statistical significance, as assessed by a one-way ANOVA $(F(3,28)=2.76, p=0.061)$ (the inset of Fig. 2a). When

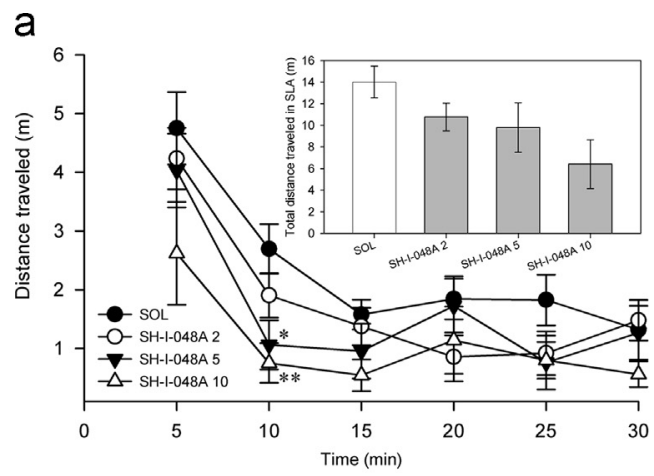

b

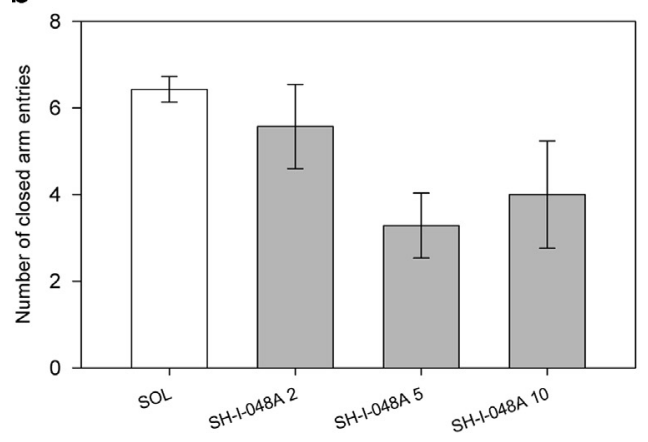

the analysis of distance traveled was developed into 5 min bins (Fig. 2a), it turned out that rats treated with SH-I-048A, dosed at 5 and $10 \mathrm{mg} / \mathrm{kg}$, traveled shorter distances than the solvent-treated animals during the second time interval (5-10 $\mathrm{min})$ ( $p=0.017$ and $p=0.008$, respectively).

\subsubsection{Elevated plus maze}

A one-way ANOVA showed no significant effect of treatment on the number of closed arm entries $(F(3,24)=2.64, p=0.072$; Fig. $2 b)$. Regarding the anxiety-related parameters, the same statistical analysis revealed that the effect of treatment on the percentage of the time spent on open arms was not significant, but again a statistical trend was noted $(F(3,24)=2.37, p=0.095$; Fig. 3a). However, ANCOVA revealed that the trend of SH-I-048A to increase this parameter, related to anxiolytic-like activity, disappeared when the concomitant influence on closed arm entries was taken into account $(F(3,23)=2.22, p=0.113)$. The doses of 0.5 and $2 \mathrm{mg} / \mathrm{kg}$ tested in a preliminary study were devoid of any influences on the EPM parameters (data not shown).

\subsubsection{Open field test}

A one-way ANOVA revealed a significant effect of treatment on the total distance traveled in the open field arena $(F(4,30)=$ 11.48, $p<0.001$; Fig. 2c). Dunnett's post hoc test showed that only SH-I-048A $(10 \mathrm{mg} / \mathrm{kg})$ significantly decreased the total distance traveled, when compared to the solvent group $(p<0.001)$. Anxiety-related parameter (the percent of time spent in the central zone) was not significantly affected, as assessed by a one-way ANOVA $(F(4,3=0.60, p=0.669$; Fig. $3 b)$.

C

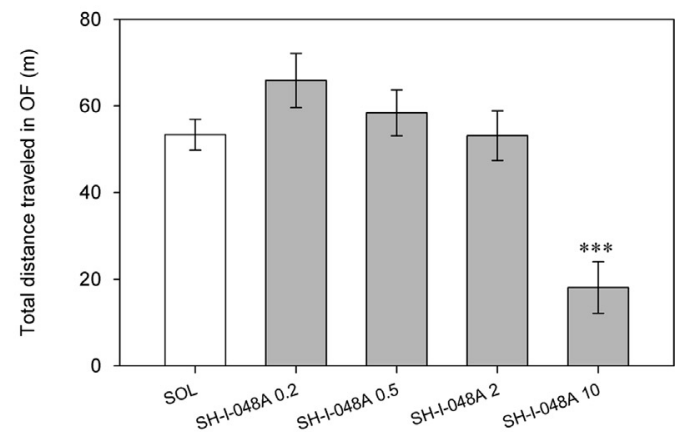

d

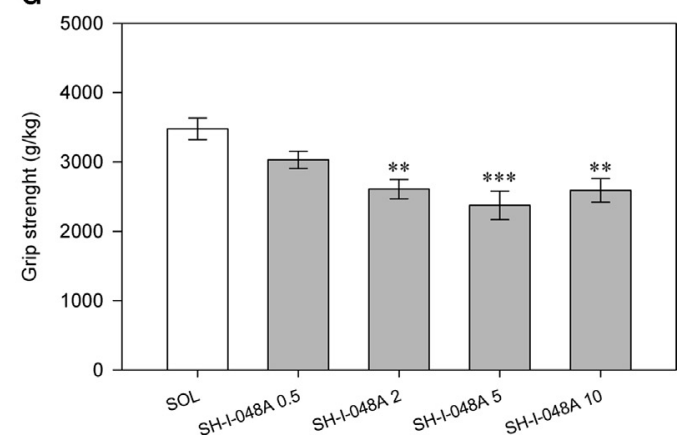

Fig. 2 - The effects of SH-I-048A on the (a) total distance traveled in spontaneous locomotor activity test, (b) number of closed arm entries of elevated plus maze, (c) total distance traveled in open field test, and (d) grip strength. ${ }^{* *} p<0.01$ and ${ }^{* * * *} p<0.001$, compared to the solvent (SOL) group. Data represent mean \pm SEM. Number of animals per each treatment group in (a) and (d) was 8, while in (b) and (c) was 7. 
a

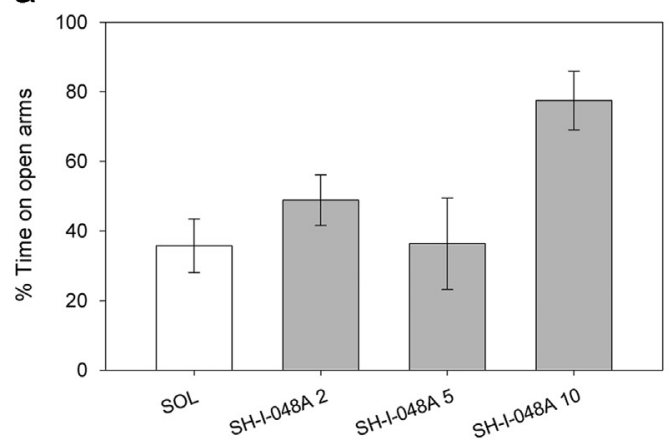

b

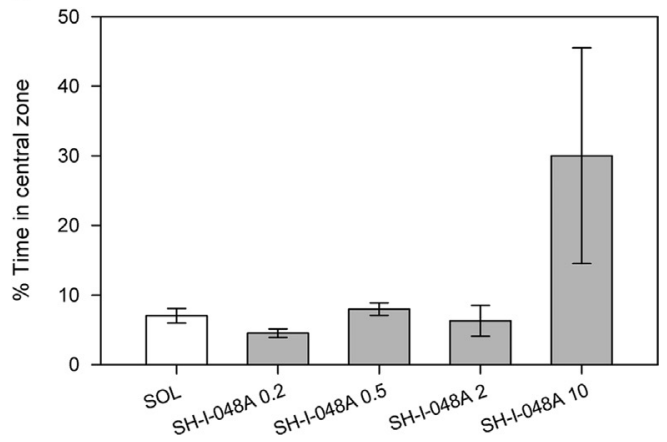

Fig. 3 - The effects of SH-I-048A (2, 5 and $10 \mathrm{mg} / \mathrm{kg})$ on the (a) percentage of time spent on open arms and (b) percentage of spent in the central zone of the open field arena. Data represent mean $\pm \mathrm{SEM}$.
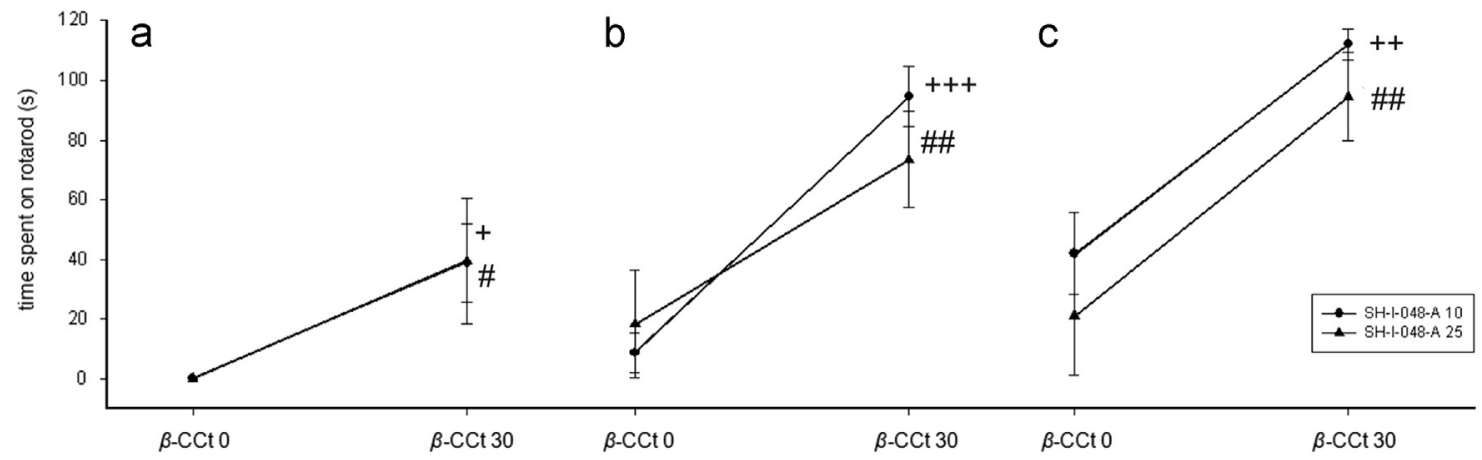

Fig. 4 - The effects of SH-I-048A (10 and $25 \mathrm{mg} / \mathrm{kg}$ ) in the absence ( $\beta$-CCt 0$)$ and the presence of $30 \mathrm{mg} / \mathrm{kg} \beta-\mathrm{CCt}(\beta-\mathrm{CCt} 30)$ on ataxia in the rotarod test: (a) $30 \mathrm{~min}$, (b) $60 \mathrm{~min}$, and (c) 90 min after treatment. ${ }^{+} p<0.05,{ }^{++} p<0.01$ and ${ }^{++} p<0.001$ compared to SH-I-048A $10+\beta$-CCt 0 group; ${ }^{*} p<0.05$ and ${ }^{\# \#} p<0.01$ compared to SH-I-048A $25+\beta$-CCt 0 group. Data represent mean \pm SEM. Number of animals per treatment varied from 6 to 8 .

\subsubsection{Grip strength test}

A one-way ANOVA revealed a significant effect of treatment on grip strength $(F(4,35)=7.48, p<0.001$; Fig. $2 d)$. Post hoc Dunnett's test showed that rats treated with SH-I-048A (2, 5 and $10 \mathrm{mg} / \mathrm{kg}$ ) experienced significant muscle relaxation compared to the control (solvent) group ( $p=0.002, p<0.001$ and $p=0.002$, respectively).

\subsubsection{Rotarod test}

When three separate two-way ANOVAs (SH-I-048A and $\beta$-CCt, as factors) were applied at each time point, the only significant factor was $\beta$-CCt (after $0.5 \mathrm{~h}: F(1,24)=9.91, p=0.004$; after $1 \mathrm{~h}$ : $F$ $(1,24)=30.02, p<0.001$, and after $1.5 \mathrm{~h}: F(1,24)=26.38, p<0.001)$. Post hoc Tukey test showed that the addition of $\beta$-CCt to both 10 and $25 \mathrm{mg} / \mathrm{kg}$ SH-I-048A increased latency to fall from the revolving rod at $0.5 \mathrm{~h}(p=0.031$ and $p=0.040$, respectively; Fig. 4a), after $1 \mathrm{~h}(p<0.001$ and $p=0.008$, respectively; Fig. $4 \mathrm{~b})$, and finally after $1.5 \mathrm{~h}(p=0.001$ and $p=0.002$, respectively; Fig. $4 \mathrm{c})$.

\subsubsection{Morris water maze}

Regarding the dose response study of SH-I-048A in the water maze, a two-way ANOVA with repeated measures revealed that only factor Days were significant, for both the latency to find the platform (treatment: $F(3,24)=0.88, p=0.467$; day: $F(4,96)=$ 46.77, $p<0.001$; and treatment $\times$ day: $F(12,96)=0.59, p=0.843$; Fig. 5a) and the path efficiency (treatment: $F(3,24)=0.89$, $p=0.463$; day: $F(4,96)=28.40, p<0.001$; and treatment $\times$ day: $F$ $(12,96)=0.61, p=0.825$; Fig. 5b). A one-way ANOVA applied on the data from the probe test revealed no significant effect of factor treatment on both parameters measured: the latency to the first entry to the target zone $(F(3,24)=0.28, p=0.841)$ and the path efficiency to the first entry to the target zone $(F(3,24)=0.73$, $p=0.542)$.

\subsubsection{Peripheral nerve injury model}

A two-way ANOVA with repeated measures showed that both factors were significant (treatment: $F(3,20)=7.83, p=0.001$; time: $F(2,40)=124.50, p<0.001$; Fig. 6). Since a significant interaction between these two factors was also determined $(F(6,40)=3.07, p=0.015)$, we decided to use one-way ANOVAs (for each of three levels of factor Time) to analyze simple main effects. A one-way ANOVA followed by Tukey's post hoc analysis showed no significant differences between all groups at the baseline time $(0 \mathrm{~h})$. After $24 \mathrm{~h}$, the same statistical procedure showed that rats treated with three doses of SH-I048A (10 mg/kg) exhibited significantly higher paw withdrawal threshold compared to the solvent group $(p=0.015)$, those treated with only one dose $(p<0.001)$, as well as to rats treated with two doses of SH-I-048A $(p=0.019)$. A one-way ANOVA applied on the data measured $48 \mathrm{~h}$ after surgery revealed no significant effect of factor Treatment on paw withdrawal threshold $(F(3,2)=1.93, p=0.157)$. Regarding the 


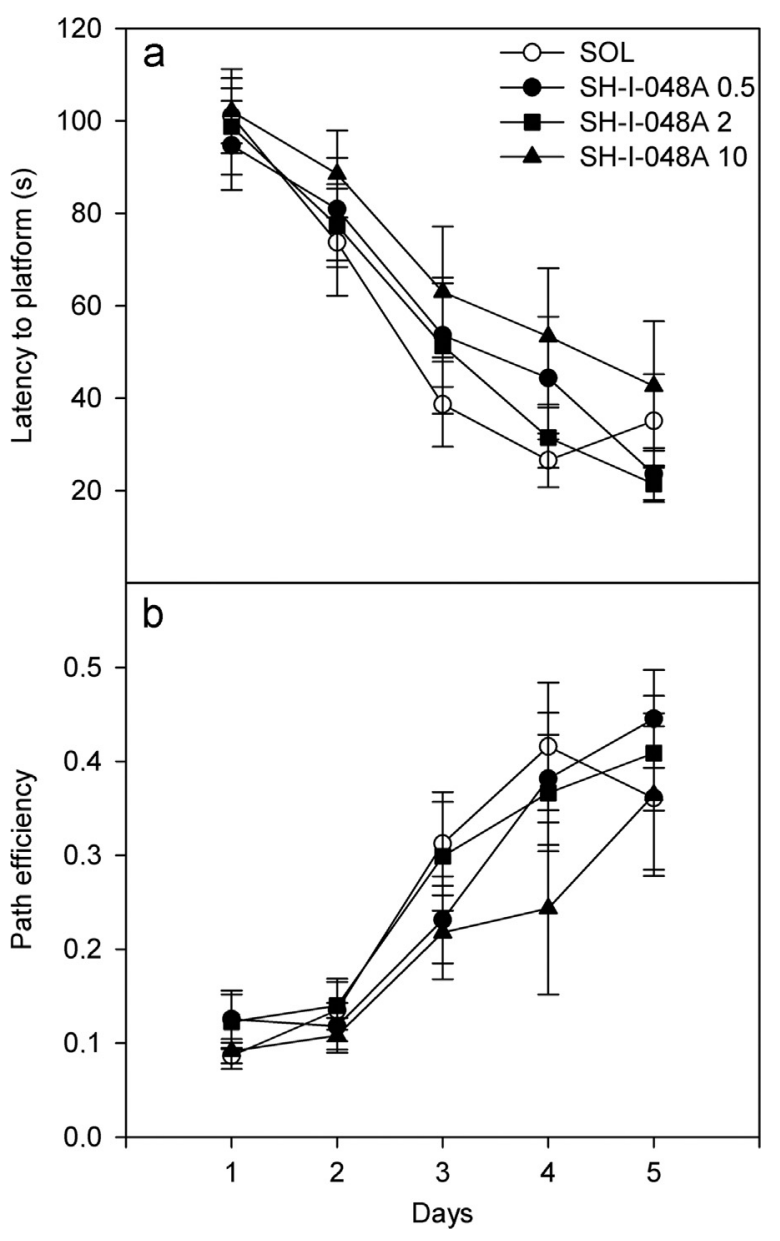

Fig. 5 - The effects of SH-I-048A $(0.5,2$ and $10 \mathrm{mg} / \mathrm{kg})$ on the water maze parameters: (a) the latency to reach the platform and (b) the path efficiency. Data represent mean \pm SEM. Number of animals per each treatment was 7 .

analysis of data for left (uninjured) hind paws, a two-way ANOVA with repeated measures showed that both factors, as well as their interaction, were without significant effect (treatment: $F(3,20)=1.99, p=0.148$; time: $F(2,40)=1.073$, $p=0.352$; and treatment $\times$ time $F(6,40)=1.98, p=0.091)$.

\subsubsection{Studies with diazepam as positive control}

Table 3 demonstrates the results of behavioral studies with $2 \mathrm{mg} / \mathrm{kg}$ diazepam in comparison to the appropriate control group and, in parallel, the above-presented data for $10 \mathrm{mg} / \mathrm{kg}$ SH-I-048A and its control. Although the effects of ligands were generally similar, the observed behavioral inactivity of SH-I048A in MWM was distinctly different from the incapacitating effect of diazepam during five days of acquisition. This finding was not accompanied by significant differences in the overall latencies during five acquisition days for solvent-treated animals from experiments with diazepam and SH-I-048A, respectively $(F(1,69)=3.169, p=0.100)$. The only significant difference between controls in two experiments was for the percent time spent in the central zone in OF (data not shown); this discrepancy was probably related to subtle differences in illumination used and also to the well-known variability of results obtained in this test (Prut and Belzung, 2003).

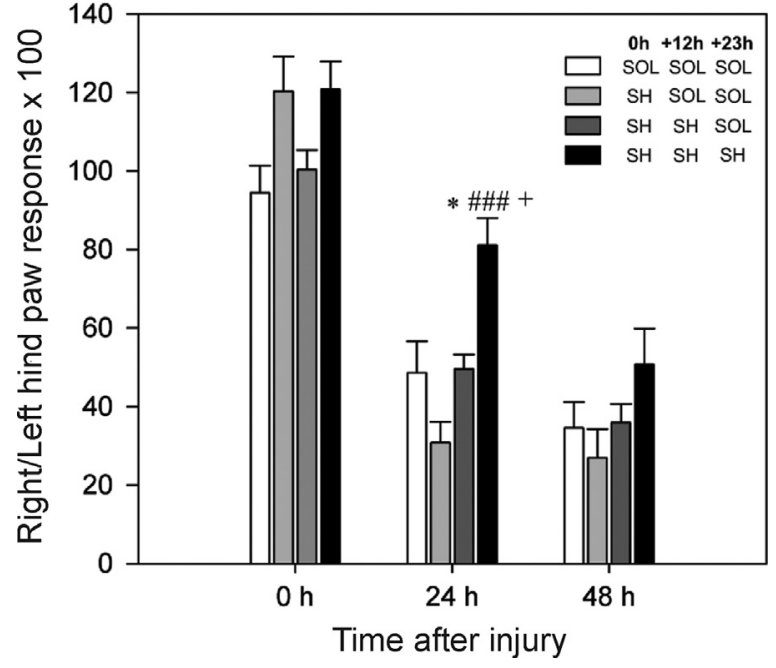

Fig. 6 - The effects of three treatment combinations comprising solvent (SOL) and/or $10 \mathrm{mg} / \mathrm{kg} \mathrm{SH-I-048A} \mathrm{(SH),}$ administered immediately after surgery $(0 \mathrm{~h}), 12 \mathrm{~h}$ later $(+12 \mathrm{~h})$ and after $23 \mathrm{~h}(+23 \mathrm{~h})$, on the ratios between the right (injured) hind paw and left hind paw responses, obtained by dividing the two values and then multiplying the result by 100 , in the peripheral nerve injury model, measured at the baseline $(0 \mathrm{~h}), 24$ and $48 \mathrm{~h}$ after injury. * $p<0.05$ compared to $3 \times$ SOL group, ${ }^{\# \# \#} p<0.001$ compared to $1 \times$ SH-I-048A $+2 \times$ SOL group, and ${ }^{+} p<0.05$ compared to $2 \times$ SH-I-048A $+1 \times$ SOL group. Data represent mean + SEM. Number of animals per each treatment group was 6 .

\section{Discussion}

In recent years, several research groups, including ours, have reported on a number of ligands for the $\mathrm{BZ}$ site of $\mathrm{GABA}_{\mathrm{A}}$ receptors which possessed in vitro selectivity for one or two populations of $\mathrm{BZ}$-sensitive receptors, and as a rule low activity at $\mathrm{GABA}_{\mathrm{A}}$ receptors containing the $\alpha_{1}$ subunit (e.g. Atack et al., 2011; Griebel et al., 2001; Mirza et al., 2008; Savić et al., 2010). Their in vivo profiles were mainly in line with the results of genetic studies, which, as a finding of special clinical relevance, associated motor impairing effects with activation of receptors containing the $\alpha_{1}$ subunit (reviewed in Rudolph and Möhler, 2006). At the same time, there have been some promising developments also of ligands reportedly non-selective in affinity and efficacy at $\mathrm{GABA}_{\mathrm{A}}$ receptors (Auta et al., 2010; Rabe et al., 2007), or even predominantly active at receptors containing the $\alpha_{1}$ subunit (Lippa et al., 2005; Popik et al., 2006), but still showing a low potential for motor deficits in animals. In order to shed some additional light on these apparently contradictory results, we discovered and pharmacologically characterized SH-I-048A, a nonselective ligand that exhibited an exceptional, subnanomolar capacity to bind to all four BZ-sensitive $\mathrm{GABA}_{\mathrm{A}}$ receptors and also strongly potentiated the inhibitory effect of GABA, mediated through these receptors. Its overall ability to change the rat's behavior was similar, but far from identical, to that characterizing diazepam at the most commonly used $2 \mathrm{mg} / \mathrm{kg}$ dose. 
Table 3 - Numeric values for diazepam (DZP, $2 \mathrm{mg} / \mathrm{kg}$ ), SH-I-048A (10 mg/kg) and their appropriate solvent controls (SOL) in behavioral experiments. Each value is the mean \pm SEM of 6-8 rats. Data for SH-I-048A and its solvent control are also graphically presented in Figs. 2-5.

\begin{tabular}{|c|c|c|c|c|c|c|}
\hline Test/parameter & SOL & DZP (2 mg/kg) & $\begin{array}{l}p \text { values } \\
\text { (SOL us. } \\
\text { DZP) }\end{array}$ & SOL & $\begin{array}{l}\text { SH-I-048A } \\
(10 \mathrm{mg} / \mathrm{kg})\end{array}$ & $\begin{array}{l}\text { p values } \\
\text { (SOL us. } \\
\text { SH-I-048A) }\end{array}$ \\
\hline SLA total distance (m) & $16.6 \pm 1.51$ & $7.17 \pm 1.13^{* * \cdots *}$ & $p<0.001$ & $14.01 \pm 1.47$ & $6.42 \pm 2.26^{*}$ & $p=0.014$ \\
\hline EPM number of closed & $5.36 \pm 0.89$ & $4.09 \pm 0.77$ & $p=0.306$ & $6.43 \pm 0.30$ & $4.00 \pm 1.23$ & $p=0.080$ \\
\hline $\begin{array}{l}\text { arm entries \% time on } \\
\text { open arms }\end{array}$ & $40.00 \pm 9.17$ & $76.67 \pm 6.67^{* * * *}$ & $p=0.009$ & $35.71 \pm 7.68$ & $67.43 \pm 12.34^{*}$ & $p=0.050$ \\
\hline OF total distance $(\mathrm{m}) \%$ & $53.91 \pm 4.68$ & $24.50 \pm 5.34^{\text {*k:k*k }}$ & $p=0.001$ & $53.36 \pm 3.56$ & $15.39 \pm 5.35^{* * * *}$ & $p<0.001$ \\
\hline time in central zone & $2.11 \pm 0.42$ & $3.09 \pm 1.15$ & $p=0.437$ & $7.04 \pm 1.06$ & $30.01 \pm 15.49$ & $p=0.165$ \\
\hline GS grip strength (g/kg) & $2698.33 \pm 211.36$ & $1722.50 \pm 197.65^{* * *}$ & $p=0.007$ & $3477.30 \pm 154.85$ & $2588.83 \pm 169.52^{* * * k}$ & $p=0.002$ \\
\hline $\mathrm{RR}$ time on rotarod (s) & $120.00 \pm 0.00$ & $41.70 \pm 9.79^{* * * *}$ & $p<0.001$ & $120.00 \pm 0.00$ & $0.25 \pm 0.16^{* * * * *}$ & $p<0.001$ \\
\hline \multicolumn{7}{|l|}{ MWM latency (s) } \\
\hline Day 1 & $73.92 \pm 9.14$ & $103.45 \pm 10.64$ & $p=0.057$ & $101.10 \pm 5.97$ & $102.11 \pm 9.11$ & $p=0.927$ \\
\hline Day 2 & $64.84 \pm 13.09$ & $92.82 \pm 6.40$ & $p=0.079$ & $73.75 \pm 11.58$ & $88.52 \pm 9.40$ & $p=0.342$ \\
\hline Day 3 & $31.57 \pm 6.37$ & $77.83 \pm 15.52^{*}$ & $p=0.017$ & $38.68 \pm 9.21$ & $62.98 \pm 14.13$ & $p=0.175$ \\
\hline Day 4 & $37.66 \pm 8.79$ & $59.02 \pm 9.78$ & $p=0.130$ & $26.56 \pm 5.82$ & $53.39 \pm 14.74$ & $p=0.116$ \\
\hline Day 5 & $17.61 \pm 3.10$ & $56.40 \pm 10.20^{* * * k}$ & $p=0.003$ & $35.11 \pm 10.09$ & $42.65 \pm 13.99$ & $p=0.670$ \\
\hline \multicolumn{7}{|c|}{$\begin{array}{l}* p<0.05 \\
* * * p<0.01 \\
* * * * x<0.001 \text { compared to the respective SOL. }\end{array}$} \\
\hline
\end{tabular}

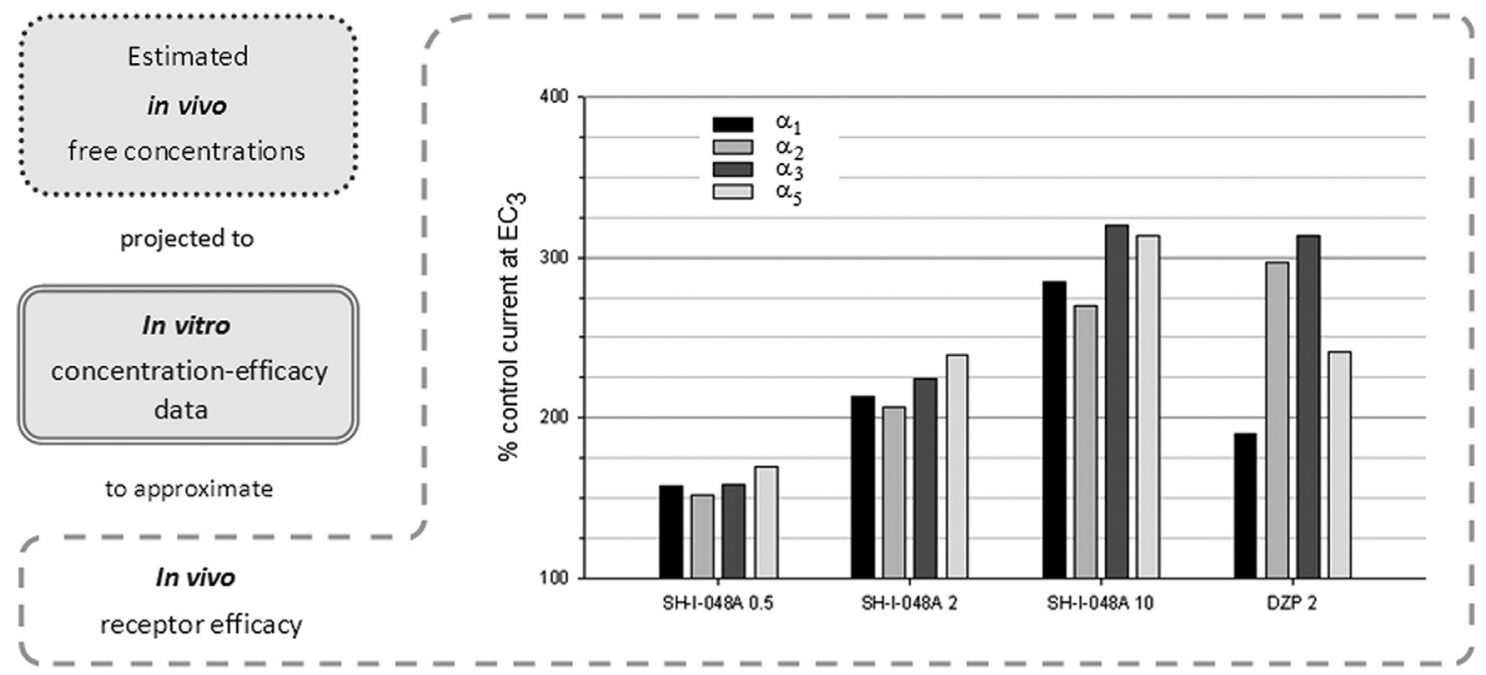

Fig. 7 - Approximated electrophysiological behavior of the estimated free brain concentrations, based on the total brain concentrations measured $20 \mathrm{~min}$ after i.p. administration of SH-I-048A (0.5, 2 and $10 \mathrm{mg} / \mathrm{kg})$ and diazepam (2 mg/kg; DZP 2). The estimated free concentrations of SH-I-048A are given in Table 2, while the estimated free concentration of $2 \mathrm{mg} / \mathrm{kg}$ diazepam equals $58.46 \mathrm{nmol} / \mathrm{kg}$ (Savić et al., unpublished data). The bars indicate the stimulation of the individual $\alpha_{x} \beta_{3} \gamma_{2}$ $\mathrm{GABA}_{\mathrm{A}}$ receptors at these concentrations, as extrapolated from data presented in Fig. 1.

The ligand SH-I-048A is structurally closely related to typical benzodiazepines such as diazepam and flurazepam, except that it contains a chiral methyl function at C-3 with the S-configuration. Previously, in another series of ligands, it was demonstrated that the binding, efficacy and in vivo activity of ligands which contain a chiral $\mathrm{S}-\mathrm{CH}_{3}$ group at $\mathrm{C}-4$ (similar to the C-3 S- $\mathrm{CH}_{3}$ function in SH-I-048A) is different than the RCH3 isomer (Fischer et al., 2010; Savić et al., 2010). Importantly, the R-enantiomer of SH-I-048A was almost completely inactive in the same oocyte assay (not shown), consequently stimulating interest in the study of chiral S-enantiomer described in this manuscript. Hence this chiral function would be expected to alter the profile of SH-I-048A us. diazepam. The question was to what extent and how.

It is generally accepted that the receptor effects, beside affinity and efficacy, depend on the available unbound ligand (Hammarlund-Udenaes, 2010; Read and Braggio, 2010). Here, we present an innovative approach aimed to compare brain exposure and electrophysiological data obtained for SH-I-048A to the results for diazepam, observed in the same experimental settings. The approximated electrophysiological responses, which the estimated free concentrations of two ligands are able to elicit (Fig. 7), suggest that the $2 \mathrm{mg} / \mathrm{kg}$ dose of diazepam corresponds to a five times higher dose of the novel ligand, at 
least after intraperitoneal administration in Wistar rats. Such a relation could not have been predicted solely from knowledge of the in vitro properties. Moreover, any discrepancies in in vivo profiles could be governed by relative differences in the approximated receptor activity of diazepam and SH-I-048A. Most remarkably, a substantial difference related to $\alpha_{1}$ - and $\alpha_{5^{-}}$ containing $\mathrm{GABA}_{\mathrm{A}}$ receptors, at which $\mathrm{SH}-\mathrm{I}-048 \mathrm{~A}$ is relatively more active than diazepam, could be noted in Fig. 7 .

SH-I-048A dose-dependently affected parameters of general motor activity and dexterity, in a manner similar to diazepam (Milić et al., 2012; Savić et al., 2009; Siemiatkowski et al., 2000). Among parameters of locomotor activity, the statistical significance of the sedative effect was reached for distance traveled during the recording period 5-10 min in SLA, at doses of 5 and $10 \mathrm{mg} / \mathrm{kg}$, and the total distance traveled in OF, at the dose of $10 \mathrm{mg} / \mathrm{kg}$. Grip strength, measuring muscle relaxant effect, was moderately, but significantly reduced at doses of $2-10 \mathrm{mg} / \mathrm{kg}$. Having in mind non-selectivity of SH-I-048A, these two sets of results conform with the postulate that sedation is mediated by $\alpha_{1}$ $\mathrm{GABA}_{\mathrm{A}}$ receptors, and muscle relaxation by $\alpha_{2}$ and $\alpha_{3} \mathrm{GABA}_{\mathrm{A}}$ receptors (Rudolph and Knoflach, 2011).

While our recent results showed that the administration of $\beta$-CCt fully antagonized the impairment of motor coordination in rats induced by diazepam (Milić et al., 2012), the antagonist effect of this $\alpha_{1}$-selective ligand on the prolonged rotarod incapacitation induced by SH-I-048A was significant, but still not sufficient enough to enable the rats to regain the control performance, especially at the $30 \mathrm{~min}$ time point, when they spent less than $40 \mathrm{~s}$ on the revolving rod, far different from the basal value of $120 \mathrm{~s}$. Since our analysis (Fig. 7) suggested a similarity of the effects of SH-I-048A and diazepam elicited at $\alpha_{2}$ and $\alpha_{3} \mathrm{GABA}_{\mathrm{A}}$ receptors, the difference in the behavioral effect has probably been contributed to the population of $\alpha_{5}$-containing GABA receptors, which are more activated by SH-I-048A than by diazepam.

Diazepam in a range of moderate doses commonly exerted anxiolytic-like actions in the EPM (Savić et al., 2010) and OF (Prut and Belzung, 2003), whereas SH-I-048A, applied in a wide range of doses $(0.5-10 \mathrm{mg} / \mathrm{kg}$ in EPM and $0.2-10 \mathrm{mg} / \mathrm{kg}$ in $\mathrm{OF}$ ), did not significantly affect the parameters of anxietyrelated behavior in either of these two anxiety tests. Moreover, the observed tendency of SH-I-048A to induce anxiolytic-like changes at the dose of $10 \mathrm{mg} / \mathrm{kg}$ appeared to be confounded by locomotor influences, as indicated by the results of statistical analysis which involved the number of closed arm entries as a covariate. We hypothesize that the motor effects mediated by an enhanced potentiation at $\alpha_{1}$ and/or $\alpha_{5} G_{A B A}$ receptors, relative do diazepam, probably hampered the anxiolytic actions of SH-I-048A expected to be effected by $\alpha_{2}$ and/or $\alpha_{3} G_{A B A}$ receptors (Rudolph and Knoflach, 2011). The results from OF and tests of motor activity suggest that even diazepam at the dose of $2 \mathrm{mg} / \mathrm{kg}$ was prone to elicit suppressing motor effects which may compromise the assessment of anxiety-like behaviors.

The results obtained in MWM demonstrated a lack of BZcharacteristic impairment of learning and memory parameters during acquisition sessions and probe trial. This finding is clearly different from the well-established incapacitating actions of diazepam (Arolfo and Brioni, 1991) and generally unexpected, especially bearing in mind the noticeable activity of SH-I-048A at $\alpha_{1}$ and $\alpha_{5}$ GABA $_{\mathrm{A}}$ receptors, which were shown to contribute to the water-maze incapacitation exerted by diazepam (Savić et al., 2009). Noteworthy, the rats dosed with $10 \mathrm{mg} / \mathrm{kg}$ SH-I-048A, apparently heavily sedated immediately before being placed into the water-maze, appeared vigilant when confronted with a challenging task. While seemingly unexplainable in the scope of the results of genetic studies (Rudolph and Knoflach, 2011), the observed 'behavioral silence' of SH-I-048A in MWM may be connected with the recent finding that potentiation of $\alpha_{5} G_{A B A}$ receptors increases firing rates of cortical neurons during episodes of ongoing neuronal activity (up states) (Drexler et al., 2013). In this vein, the observed higher activity at $\alpha_{5} G_{A B A}$ receptors of SH-I-048A compared to diazepam may have contributed to a kind of compensatory effect on MWM performance, noted in the current investigation.

The decrease of GABA neurotransmission in the spinal cord contributes to the enhanced pain sensitivity observed in pain states, especially those of neuropathic nature (Munro et al., 2009). At the behavioral level, it was shown that $\mathrm{GABA}_{\mathrm{A}}$ receptor positive allosteric modulators, such as diazepam, attenuate nociceptive transmission in animal models of neuropathic pain (Knabl et al., 2009; Malan et al., 2002). The present study has focused on sciatic crush injury (Bester et al., 2000), which mimics a common and refractory disability. SH-I-048A, administered in three $10 \mathrm{mg} / \mathrm{kg}$ doses, has reversed mechanical hyperalgesia $24 \mathrm{~h}$ after injury, as measured $1 \mathrm{~h}$ after administration of the last dose. Motor incapacitation elicited by the novel ligand, demonstrated in tests of motor function, cannot be seen as substantially confounding these results, having in mind normal responses of uninjured hind paws. Although the antihyperalgesic influence of treatment was statistically not significant $48 \mathrm{~h}$ after injury, there was still a certain level of the residual effect in the group injected thrice with SH-I-048A. In the more common chronic constriction injury model, which could be regarded as similar to the crush injury model used in the present study, it was shown that diazepam was able to attenuate hind paw hypersensitivity at the highest dose tested (10 mg/kg) (Munro et al., 2008). On the contrary, zolpidem, a positive modulator highly effective at $\alpha_{1^{-}}$, moderately effective at $\alpha_{2 / 3^{-}}$and ineffective at $\alpha_{5} \mathrm{GABA}_{\mathrm{A}}$ receptors (Savić et al., 2010), was completely inactive in the same model (Munro et al., 2008). Genetic and pharmacological studies have focused on the role of benzodiazepines in central pain transmission on the population of $\alpha_{2 / 3} G_{A B A}$ receptors (Di Lio et al., 2011; Knabl et al., 2008). However, a number of studies have pointed to $\alpha_{5}$-containing receptors as possibly contributing to GABA-mediated antihyperalgesia (Nickolls et al., 2011). A substantial potential of antihyperalgesic action of SH-I-048A dosed thrice at $10 \mathrm{mg} / \mathrm{kg}$ may be seen as further adding to the possible role of $\alpha_{5} \mathrm{GABA}_{\mathrm{A}}$ receptors, otherwise moderately present in the spinal cord (Paul et al., 2012), in modulation of pain transmission.

In conclusion, this paper presented SH-I-048A, a novel, chiral, highly potent and efficacious positive allosteric modulator at the $\mathrm{BZ}$ site of recombinant $\mathrm{GABA}_{\mathrm{A}}$ receptors. Apparently small differences in the simulated in vivo environment, approximated on the basis of electrophysiological, equilibrium 
dialysis and rat brain exposure studies, have been reflected in a number of differences in behavioral profiles of SH-I-048A and diazepam, which may be connected with relatively higher activity of SH-I-048A at $\alpha_{1}$ and/or $\alpha_{5}$ GABA $_{\mathrm{A}}$ receptors. It appears crucial to establish firmer links between in vitro and in vivo data in order to help define the criteria for declaring selectivity or non-selectivity of $\mathrm{BZ}$ site ligands, and the presented approximation of activation of $\mathrm{GABA}_{\mathrm{A}}$ receptor subtypes may be a valuable approach. The current results suggest that diazepam, commonly seen as a prototype of nonselective $\mathrm{BZ}$ site ligands, does possess a kind of 'semi-selectivity' towards $\alpha_{2}$ and $\alpha_{3} \mathrm{GABA}_{\mathrm{A}}$ receptors, far different from SH-I-048A, which thus proved to be a useful experimental tool.

\section{Experimental procedures}

\subsection{Drugs}

The novel chiral compound SH-I-048A ((S)-7-bromo-5-(2fluorophenyl)-3-methyl-1H-benzo[e][1,4]diazepin-2(3H)-one) and $\beta$-CCt (t-butyl- $\beta$-carboline-3-carboxylate), the preferential $\alpha_{1}$-containing $\mathrm{GABA}_{\mathrm{A}}$ receptor selective antagonist, were synthesized at the Department of Chemistry and Biochemistry, University of Wisconsin - Milwaukee, while diazepam was obtained from Galenika (Belgrade, Serbia).

\subsection{Competition binding assays}

Competition binding assays were performed in a total volume of $0.5 \mathrm{~mL}$ at $4{ }^{\circ} \mathrm{C}$ for $1 \mathrm{~h}$ using $\left[{ }^{3} \mathrm{H}\right]$ flunitrazepam as the radiolabelled ligand. A total of $6 \mu \mathrm{g}$ of cloned human $\mathrm{GABA}_{\mathrm{A}}$ receptor DNA containing the desired $\alpha$ subtype along with $\beta_{2}$ and $\gamma_{2}$ subunits were used for transfecting HEK 293T cell lines using Fugene 6 (Roche Diagnostic) transfecting reagent. Cells were harvested $48 \mathrm{~h}$ after transfection, washed with Tris-HCl buffer ( $\mathrm{pH}$ 7.0) and Tris-acetate buffer ( $\mathrm{pH}$ 7.4) and the resulting pellets were stored at $-80^{\circ} \mathrm{C}$ until assayed. On the day of the assay, pellets containing $20-50 \mu \mathrm{g}$ of $\mathrm{GABA}_{\mathrm{A}}$ receptor protein were resuspended in $50 \mathrm{mM}$ Tris-acetate $\mathrm{pH} 7.4$ at $4{ }^{\circ} \mathrm{C}$ and incubated with the radiolabel as previously described (Choudhary et al., 1992). Nonspecific binding was defined as radioactivity bound in the presence of $100 \mu \mathrm{M}$ diazepam and represented less than $20 \%$ of total binding.

Membranes were harvested with a Brandel cell harvester followed by three ice-cold washes onto polyethyleneiminepretreated $(0.3 \%)$ Whatman GF/C filters. Filters were dried overnight and then soaked in Ecoscint A liquid scintillation cocktail (National Diagnostics; Atlanta, GA). Bound radioactivity was quantified by liquid scintillation counting. Membrane protein concentrations were determined using an assay kit from Bio-Rad (Hercules, CA) with bovine serum albumin as the standard.

\subsection{Electrophysiological experiments}

cDNAs of rat $\mathrm{GABA}_{\mathrm{A}}$ receptor subunits were used for generating the respective mRNA's that were then injected into Xenopus laevis oocytes (Nasco, WI) as described previously (Ramerstorfer et al., 2010). For electrophysiological recordings, oocytes were placed on a nylon-grid in a bath of Xenopus Ringer solution (XR, containing $90 \mathrm{mM} \mathrm{NaCl}, 5 \mathrm{mM}$ HEPES-NaOH (pH 7.4), $1 \mathrm{mM}$ $\mathrm{MgCl}_{2}, 1 \mathrm{mM} \mathrm{KCl}$ and $1 \mathrm{mM} \mathrm{CaCl} 2$ ). The oocytes were constantly washed by a flow of $6 \mathrm{~mL} / \mathrm{min} \mathrm{XR}$ which could be switched to XR containing GABA and/or drugs. Drugs were diluted into XR from DMSO-solutions resulting in a final concentration of $0.1 \%$ DMSO perfusing the oocytes. Drugs were preapplied for $30 \mathrm{~s}$ before the addition of GABA, which was coapplied with the drugs until a peak response was observed. Between two applications, oocytes were washed in XR for up to $15 \mathrm{~min}$ to ensure full recovery from desensitization. To test for modulation of GABA-induced currents by drugs, a concentration of GABA was used that was titrated to trigger $3 \%$ of the respective maximum GABA-elicited current of the individual oocyte $\left(\mathrm{EC}_{3}\right)$. At this low GABA concentration, within-day and between-day currents are reproducible and effects of drugs (\% of modulation) are much higher than that at higher GABA concentrations, again contributing to the accuracy of the results. In addition, such low GABA concentrations correspond to those acting at extrasynaptic receptors that represent the majority of $\mathrm{GABA}_{\mathrm{A}}$ receptors in the brain (Kasugai et al., 2010). In contrast, GABA concentrations acting at synaptic $\mathrm{GABA}_{\mathrm{A}}$ receptors in many cases fully activate these receptors. At such GABA concentrations benzodiazepines cannot enhance GABA currents anymore, but they prolong current decay. This effect, however, is antagonized by a simultaneously occurring rapid receptor desensitization making measurements unreliable. The GABA $\mathrm{EC}_{3}$ concentration was applied to the cell together with various concentrations of drugs. For current measurements the oocytes were impaled with two microelectrodes (2-3 m $\Omega$ ) which were filled with $2 \mathrm{mM} \mathrm{KCl}$. All recordings were performed at room temperature at a holding potential of $-60 \mathrm{mV}$ using a Warner OC-725C two-electrode voltage clamp (Warner Instruments, Hamden, CT). Data were digitized, recorded and measured using a Digidata 1322A data acquisition system (Axon Instruments, Union City, CA). Results of concentration response experiments were graphed using GraphPad Prism 4.00 (GraphPad Software, San Diego, CA).

Maximum GABA-evoked currents (1 mM GABA) were measured in each oocyte and were in the 4.5-7 $\mu \mathrm{A}$ range for all receptor subtypes investigated, indicating an adequate expression of the different receptor subtypes. From these data, $\mathrm{GABA} \mathrm{EC}_{3}$ values were calculated and the oocytes were then stimulated by the respective GABA concentration, confirming the calculated value. The $\mathrm{GABA} \mathrm{EC}_{3}$ current was then modulated by $1 \mu \mathrm{M}$ diazepam, which should nearly maximally modulate the receptors. Further measurements with the oocyte were only performed if the extent of modulation by diazepam was in a range corresponding to that shown in Fig. $1 \mathrm{~b}$ for the respective receptor subtype.

\subsection{Estimation of free plasma and brain concentrations}

4.4.1. Quantification in rat plasma and brain tissue Eighteen Wistar male rats (180-220 g, Military Farm, Belgrade, Serbia) were divided into six treatment groups (3 animals per group) that intraperitoneally (i.p.) received $0.5 \mathrm{mg} / \mathrm{kg}$ SH-I-048A $20 \mathrm{~min}$ before decapitation, 2 or $10 \mathrm{mg} / \mathrm{kg}$ SH-I-048 A 20 or $60 \mathrm{~min}$ before decapitation, or solvent. Blood samples were collected by cardiac puncture into heparinized tubes then 
centrifuged at $2500 \mathrm{~g}$ for $10 \mathrm{~min}$ to obtain plasma. Thereafter, brains were rapidly removed, measured and homogenized at $16,000 \mathrm{rpm}$ for $2 \mathrm{~min}$ by a rotor-stator blender ( $\mathrm{T} 25$ digital Ultra-Turrax, IKA, Germany) in $2 \mathrm{~mL}$ of methanol. The final volume was adjusted to $5 \mathrm{~mL}$ with methanol and after centrifugation (6000g for $20 \mathrm{~min}$ ) supernatants were collected.

Concentrations of SH-I-048 A in plasma and brain tissue were determined by ultra performance liquid chromatographytandem mass spectrometry (UPLC/MS/MS). The sample pretreatment procedure was carried out using solid-phase extraction (SPE) on Oasiss HLB cartridges (Waters, Milford, MA, USA). The procedure was adapted from the method reported by Mercolini et al. (2009). Briefly, cartridges preconditioned with methanol and water were loaded with samples (plasma or supernatant of brain tissue homogenate) and the internal standard solution. Endogenous impurities were removed by washing the cartridges with water and methanol. Finally, analyte elution was carried out with $1 \mathrm{~mL}$ of methanol for $1 \mathrm{~min}$.

\subsubsection{Plasma protein and brain tissue binding studies}

A 48-well rapid equilibrium dialysis (RED) device (Thermo Scientific) was used to determine SH-I-048 A free fraction in fresh rat plasma and brain tissue. Brain samples were diluted with 4 volumes of PBS and homogenized. The sample chambers of the RED device insert were loaded with $190 \mu \mathrm{L}$ of plasma or brain tissue homogenate and $10 \mu \mathrm{L}$ of SH-I-048A working solution in DMSO $(100 \mu \mathrm{M})$ in order to obtain a final SH-I-048A concentration of $5 \mu \mathrm{M}$. A $350 \mu \mathrm{L}$ of PBS were transferred into the buffer chamber of the insert. After incubation at $37^{\circ} \mathrm{C}$ on an orbital shaker for $4 \mathrm{~h}, 50 \mu \mathrm{L}$ of buffer, plasma and brain homogenate aliquots were transferred to microcentrifuge tubes containing equal volume of DMSO. A $50 \mu \mathrm{L}$ volume of control buffer was added to the plasma and brain homogenate samples and $50 \mu \mathrm{L}$ of either control brain homogenate or control plasma was added to the buffer sample to yield an identical matrix between buffer and nonbuffer samples. Sample extraction was performed by the addition of $300 \mu \mathrm{L}$ of chilled acetonitrile containing midazolam as an internal standard. After vortexing and centrifuging, $120 \mu \mathrm{L}$ of supernatant were transferred to vials for UPLC/MS/MS analysis. The same protocol was applied for the matrix preparation for standard curves except that $50 \mu \mathrm{L}$ of drug-free dialyzed plasma, brain homogenate and buffer were added to microcentrifuge tubes containing $50 \mu \mathrm{L}$ of SH-I-048A standard solutions in DMSO over the concentration range from $50 \mu \mathrm{M}$ to $0.5 \mu \mathrm{M}$.

The unbound fraction in plasma was determined as the ratio of concentrations determined in buffer to that determined in plasma. The unbound fraction in undiluted brain was calculated by using the following equation: undiluted $\mathrm{fu}=\left\{1 / \mathrm{D} *\left[\left(1 / \mathrm{fu}_{\text {(apparent) }}-1\right)+1 / \mathrm{D}\right]\right\}$ (Kalvass and Maurer, 2002), where $D$ and $\mathrm{fu}_{\text {(apparent) }}$ represent dilution factor and free fraction determined as the ratio of concentrations in buffer us. diluted brain tissue, respectively.

\subsection{Behavioral experiments}

In vivo studies were carried out on male Wistar rats (Military Farm, Belgrade, Serbia), weighing 180-220 g at the beginning of the experiments. All procedures in the study conformed to EEC Directive 86/609 and were approved by the Ethical
Committee on Animal Experimentation of the Faculty of Pharmacy in Belgrade, or, for the peripheral nerve injury model, Medical Faculty in Belgrade. The rats were grouphoused four per cage (in the peripheral nerve injury model two per cage) in transparent plastic cages with tap water and food pellets available ad libitum and kept under a $12 \mathrm{~h}$ light/ dark cycle (light on at 6:00 h). The temperature of the animal room was $22 \pm 1{ }^{\circ} \mathrm{C}$, the relative humidity is $40-70 \%$ and the illumination is $120 \mathrm{~lx}$. With the exception of the second treatment in the peripheral nerve injury model, all handling and testing took place during the light period of the cycle. Ligands were dissolved/suspended with the aid of sonication in solvent containing $85 \%$ distilled water, $14 \%$ propylenegly$\mathrm{col}$, and $1 \%$ Tween 80 , and were administered i.p. in a volume of $1 \mathrm{~mL} / \mathrm{kg}$.

Separate groups of naïve animals were used for seven behavioral paradigms. For all behavioral studies, with the exception of the peripheral nerve injury model, the positive control experiments $(2 \mathrm{mg} / \mathrm{kg}$ diazepam, with the accompanying solvent control) have been performed separately during the period when experiments with SH-I-048 A were carried out. The behavior in spontaneous locomotor activity (SLA), open field (OF), Morris water maze (MWM) and elevated plus maze (EPM) was recorded by a ceiling-mounted camera and analyzed by the ANY-maze Video Tracking System software (Stoelting Co., Wood Dale, IL, USA). The rats' behavior in rotarod (RR) and grip strength (GS) tests, as well as in peripheral nerve injury (PNI) model, was recorded automatically by the apparatus. Where applicable, olfactory traces left in the apparatus were removed after each testing using diluted ethanol.

\subsubsection{Spontaneous locomotor activity test}

The rats' spontaneous locomotor activity was monitored in a clear Plexiglas open chamber $(40 \times 25 \times 35 \mathrm{~cm})$ without any prior habituation to this apparatus. Twenty minutes after receiving the appropriate treatment, a single rat was placed in the chamber, under dimmed red light (20 lx), and activity was recorded for a total of $30 \mathrm{~min}$. The total distance traveled $(m)$ was the activity parameter evaluated in four treatment groups (solvent and SH-I-048 A, dosed at 2, 5 and $10 \mathrm{mg} / \mathrm{kg}$ ). Besides the total distance traveled, behavior was analyzed by breaking the locomotor activity data into 5-min bins.

\subsubsection{Elevated plus maze test}

The apparatus was constructed of sheet metal, with a black rubber floor. It consisted of a maze elevated to a height of $50 \mathrm{~cm}$ with two open $(50 \times 10 \mathrm{~cm})$ and two enclosed arms $(50 \times 10 \times 40 \mathrm{~cm})$, connected by a junction area measuring $10 \times 10 \mathrm{~cm}$. A ledge of sheet metal $(0.3 \mathrm{~cm}$ high) surrounded the open arms. The red illumination on the surface of the closed arms was $10 \mathrm{~lx}$. At the beginning of the experiment, single rats were placed in the center of the maze, facing one of the enclosed arms, and their behavior was recorded for $5 \mathrm{~min}$. An entry into an open or closed arm was scored when $80 \%$ of the animal crossed the virtual line separating the central square of the maze from the arm, whereas an exit occurred when more than $80 \%$ of the animal left the respective arm. In this experiment we used four treatment groups: solvent and SH-I-048A dosed at 2, 5 and $10 \mathrm{mg} / \mathrm{kg}$. In a preliminary study, we tested also the $0.5 \mathrm{mg} / \mathrm{kg}$ dose of SH-I-048A. 


\subsubsection{Open field test}

The OF arena consisted of a square wooden box $\left(100 \times 100 \times 50 \mathrm{~cm}^{3}\right)$, with a black rubber floor. Twenty minutes after receiving the appropriate treatment, and without any prior habituation, a single animal was placed in the center of the box. The central $16 \%$ of the floor surface $\left(40 \times 40 \mathrm{~cm}^{2}\right)$ was virtually set as a central zone. Animal activity under dimmed red light (20lx) was recorded for $15 \mathrm{~min}$. The total distance traveled $(\mathrm{m})$ was evaluated as an activity parameter, while the percent of time spent in the central zone, as an anxiety-related parameter, was estimated in the first 5-min period. In this experiment we used five treatment groups: solvent and SH-I-048A dosed at 0.2, 0.5, 2 and $10 \mathrm{mg} / \mathrm{kg}$.

\subsubsection{Grip strength test}

Myorelaxant properties of SH-I-048A, dosed at 0.5, 2, 5 and $10 \mathrm{mg} / \mathrm{kg}$, were examined in this study. Twenty minutes after administration of the appropriate treatment rats were allowed to grasp with their front paws a metal trapezoid wire grid attached to a grip-strength meter (Ugo Basile, Italy), while being lifted by the tail with increasing firmness until they loosened their grip. Every testing was performed by the same experimenter. The apparatus measured the pull force (expressed in grams) necessary to overcome the animal's forelimbs grip-strength. Each animal was given three consecutive trials and the median value was taken in the statistics. Dependent variable chosen was calculated by dividing the pull force with the rat's body weight.

\subsubsection{Rotarod test}

Motor performance was assessed using an automated rotarod (Ugo Basile, Italy). Before testing, rats were trained for three days until they could remain on a revolving rod for $120 \mathrm{~s}$ with acceleration from $15 \mathrm{rpm}$ to $25 \mathrm{rpm}$. During the training days, all animals were given three training sessions of 2 min each, with a $30 \mathrm{~min}$ inter-session interval. On the fourth day, selection was made and rats that fit the given criteria were included in the experiment. Four groups received one of the following treatments: SH-I-048A (10 and $25 \mathrm{mg} / \mathrm{kg}$ ) alone or in combination with $\beta$-CCt $(30 \mathrm{mg} / \mathrm{kg})$. Latency to fall from the rotarod was recorded automatically for each animal after 30 , 60 and $90 \mathrm{~min}$.

\subsubsection{Morris water maze test}

The water maze consisted of a black cylindrical pool (diameter, $200 \mathrm{~cm}$; height, $60 \mathrm{~cm}$ ) filled to a height of $30 \mathrm{~cm}$ with $23^{\circ} \mathrm{C}\left( \pm 1{ }^{\circ} \mathrm{C}\right)$ water. The escape platform made of black plastic $(15 \times 10 \mathrm{~cm})$ was submerged $2 \mathrm{~cm}$ below the water surface. An indirect illumination in the experimental room was provided by white neon tubes. The rats received the appropriate treatment 20 min before a swimming block, each day for 5 consecutive days of spatial acquisition. Each block consisted of 4 trials, lasting a maximum time of $120 \mathrm{~s}$, the intertrial interval being $60 \mathrm{~s}$. For each trial the rat was placed in the water facing the pool at one of four pseudorandomly determined starting positions. Since the platform was hidden in the middle of the NE quadrant during spatial learning, the four distal start locations were S, W, NW and SE. Once the rat found and mounted the escape platform, it was permitted to remain on it for $15 \mathrm{~s}$. The rat was guided to the platform by the experimenter if it did not locate the escape within $120 \mathrm{~s}$. For each training day and parameter measured in the water maze the mean value was calculated for each rat (total data/ total number of trials). To assess the reference memory at the end of the learning period, a probe trial was conducted $24 \mathrm{~h}$ after the last acquisition day. The probe trial, starting from the novel, most distant SW location, with the platform omitted, lasted $60 \mathrm{~s}$ and was performed without any pretreatment. The tracking software virtually divided the pool into four quadrants, three concentric annuli and a target region consisting of the intersection of the platform quadrant and the platform (middle) annulus, as graphically represented in Savić et al. (2009).

Dependent variables chosen for tracking during the acquisition trials were the latency to reach the platform (time from the start to the goal) and the path efficiency (the ratio of the shortest possible path length to actual path length). In addition, the latency to the first entry to the target zone and the path efficiency to the first entry to the target zone were assessed during the probe trial. In the water maze study we used four treatment groups: solvent and SH-I-048A dosed at $0.5,2$ and $10 \mathrm{mg} / \mathrm{kg}$.

\subsubsection{Peripheral nerve injury model}

The animals were habituated in individual Plexiglas chambers for $30 \mathrm{~min}$ before testing. Electronic von Frey apparatus (Model 2390, IITC Life Science - USA) was used to determine paw withdrawal threshold expressed in grams. An increasing pressure of maximum $80 \mathrm{~g}$ was intermittently applied to the right and left rat hind paw for three times each, until the animal showed a typical paw withdrawal reaction. Baseline withdrawal scores were obtained before injury $(0 \mathrm{~h})$. To induce PNI model, we performed a crush injury to the right sciatic nerve. Rats were anesthetized with ketamine solution (10\% Ketamidor, Richter Pharma Ag, Wels, Austria). After the right external thigh and buttock area had been shaved, the skin was properly prepared with antiseptic solution and alcohol, and small incision was made. The $\mathrm{m}$. vastus lateralis and $\mathrm{m}$. biceps femoralis were bluntly separated at the mid-thigh level. The nerve was kept in situ. At approximately $7 \mathrm{~mm}$ from the point of its emergence, the common sciatic nerve was mobilized and traumatized by a single 30-s crush with a serrated hemostat (Bridge et al., 1994). After surgery animals were separated in four groups. Treatments were administered three times: immediately after surgery, after $12 \mathrm{~h}$ and finally after $23 \mathrm{~h}$. The treatment groups were solvent three times, one dose of SH-I-048A $(10 \mathrm{mg} / \mathrm{kg})$; solvent two times, two doses of SH-I-048A $(10 \mathrm{mg} / \mathrm{kg})$; and solvent once and three doses of SH-I-048A (10 mg/kg). After 24 and $48 \mathrm{~h}$, mechanical hyperalgesia was determined in both hind paws. The graph shows the ratios between the right hind paw and left hind paw responses, obtained by dividing the two values and then multiplying the result by 100 for a better graph representation.

\subsection{Statistical analysis}

For electrophysiological data, as well as for behavioral data presented in Table 3, Student's t-test was used. Other 
behavioral data sets were checked for homogeneity of variance and normality prior to analysis by a one-way ANOVA (SLA, OF, EPM and GS tests), or a two-way ANOVA (RR test). In order to fully investigate the rats' behavior in the EPM, an analysis of covariance (ANCOVA) was performed for the percentage of time spent on open arms, as an anxiety-related parameter, using the number of enclosed arm entries as covariate. Data from MWM and PNI model were assessed with a two-way ANOVA with repeated measures (treatment as between-subject factor and day or time, respectively, as within-subject factor). In the case of significant interaction, separate one-way ANOVAs were conducted to assess the influence of one factor within individual levels of other factor. For post hoc analysis, Dunnett's or Tukey's test were used. Statistical analyses were performed with ANY-maze Video Tracking System software (Stoelting Co., Wood Dale, IL, USA) and Sigma Plot 11 (Systat Software Inc., Richmond, CA, USA). Differences were considered to be statistically significant when $p$ was less than 0.05 , while $0.1>p>0.05$ was considered as a trend toward significance.

\section{Acknowledgement}

This work was supported in part by The Ministry of Science, R. Serbia - Grant No. 175066 (MMS) and by NIMH 46851 (JMC).

\section{R E F E R E N C E S}

Arolfo, M.P., Brioni, J.D., 1991. Diazepam impairs place learning in the Morris water maze. Behav. Neural Biol. 55, 131-136.

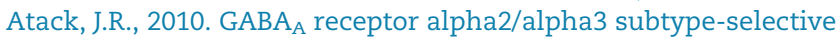
modulators as potential nonsedating anxiolytics. Curr. Top. Behav. Neurosci. 2, 331-360.

Atack, J.R., Wafford, K.A., Street, L.J., Dawson, G.R., Tye, S., Van Laere, K., et al., 2011. MRK-409 (MK-0343), a GABA $A_{A}$ receptor subtype-selective partial agonist, is a non-sedating anxiolytic in preclinical species but causes sedation in humans. J. Psychopharmacol. 25, 314-328.

Auta, J., Kadriu, B., Giusti, P., Costa, E., Guidotti, A., 2010. Anticonvulsant, anxiolytic, and non-sedating actions of imidazenil and other imidazo-benzodiazepine carboxamide derivatives. Pharmacol. Biochem. Behav. 95, 383-389.

Bester, H., Beggs, S., Woolf, C.J., 2000. Changes in tactile stimuliinduced behavior and c-Fos expression in the superficial dorsal horn and in parabrachial nuclei after sciatic nerve crush. J. Comp. Neurol. 428, 45-61.

Bridge, P.M., Ball, D.J., Mackinnon, S.E., Nakao, Y., Brandt, K., Hunter, D.A., et al., 1994. Nerve crush injuries - a model for axonotmesis. Exp. Neurol. 127, 284-290.

Choudhary, M.S., Craigo, S., Roth, B.L., 1992. Identification of receptor domains that modify ligand binding to 5hydroxytryptamine2 and 5-hydroxytryptamine1c serotonin receptors. Mol. Pharmacol. 42, 627-633.

Di Lio, A., Benke, D., Besson, M., Desmeules, J., Daali, Y., Wang, Z. J., Edwankar, R., Cook, J.M., Zeilhofer, H.U., 2011. HZ166, a novel $\mathrm{GABA}_{\mathrm{A}}$ receptor subtype-selective benzodiazepine site ligand, is antihyperalgesic in mouse models of inflammatory and neuropathic pain. Neuropharmacology 60, 626-632.

Drexler, B., Zinser, S., Huang, S., Poe, M.M., Rudolph, U., Cook, J. M., et al., 2013. Enhancing the function of alpha5-subunitcontaining $\mathrm{GABA}_{\mathrm{A}}$ receptors promotes action potential firing of neocortical neurons during up-states. Eur. J. Pharmacol. 703, 18-24.
Fischer, B.D., Licata, S.C., Edwankar, R.V., Wang, Z.J., Huang, S., He, X., et al., 2010. Anxiolytic-like effects of 8-acetylene imidazobenzodiazepines in a rhesus monkey conflict procedure. Neuropharmacology 59, 612-618.

Gill, K.M., Lodge, D.J., Cook, J.M., Aras, S., Grace, A.A., 2011. A novel $\alpha 5 G A B A(A) R$-positive allosteric modulator reverses hyperactivation of the dopamine system in the MAM model of schizophrenia. Neuropsychopharmacology 36, 1903-1911.

Griebel, G., Perrault, G., Simiand, J., Cohen, C., Granger, P., Decobert, M., et al., 2001. SL651498: an anxioselective compound with functional selectivity for alpha2- and alpha3containing gamma-aminobutyric acid(A) (GABA(A)) receptors. J. Pharmacol. Exp. Ther. 298, 753-768.

Hammarlund-Udenaes, M., 2010. Active-site concentrations of chemicals - are they a better predictor of effect than plasma/ organ/tissue concentrations?. Basic Clin. Pharmacol. Toxicol. 106, 215-220.

Kalvass, J.C., Maurer, T.S., 2002. Influence of nonspecific brain and plasma binding on CNS exposure: implications for rational drug discovery. Biopharm. Drug Dispos. 23, 327-338.

Kasugai, Y., Swinny, J.D., Roberts, J.D., Dalezios, Y., Fukazawa, Y., Sieghart, W., Shigemoto, R., Somogyi, P., 2010. Quantitative localisation of synaptic and extrasynaptic $\mathrm{GABA}_{\mathrm{A}}$ receptor subunits on hippocampal pyramidal cells by freeze-fracture replica immunolabelling. Eur. J. Neurosci. 32, 1868-1888.

Knabl, J., Witschi, R., Hösl, K., Reinold, H., Zeilhofer, U.B., Ahmadi, S., et al., 2008. Reversal of pathological pain through specific spinal $\mathrm{GABA}_{\mathrm{A}}$ receptor subtypes. Nature 451, 330-334.

Knabl, J., Zeilhofer, U.B., Crestani, F., Rudolph, U., Zeilhofer, H.U., 2009. Genuine antihyperalgesia by systemic diazepam revealed by experiments in $\mathrm{GABA}_{\mathrm{A}}$ receptor point-mutated mice. Pain 141, 233-238.

Koh, M.T., Rosenzweig-Lipson, S., Gallagher, M., 2013. Selective GABA(A) $\alpha 5$ positive allosteric modulators improve cognitive function in aged rats with memory impairment. Neuropharmacology 64, 145-152.

Lippa, A., Czobor, P., Stark, J., Beer, B., Kostakis, E., Gravielle, M., et al., 2005. Selective anxiolysis produced by ocinaplon, a GABA(A) receptor modulator. Proc. Natl. Acad. Sci. U. S. A. 102, 7380-7385.

Malan, T.P., Mata, H.P., Porreca, F., 2002. Spinal GABA(A) and GABA (B) receptor pharmacology in a rat model of neuropathic pain. Anesthesiology 96, 1161-1167.

McEown, K., Treit, D., 2013. A2 GABAA receptor sub-units in the ventral hippocampus and $\alpha 5$ GABAA receptor sub-units in the dorsal hippocampus mediate anxiety and fear memory. Neuroscience 252, 169-177.

Mercolini, L., Mandrioli, R., Iannello, C., Matrisciano, F., Nicoletti, F., Raggi, M.A., 2009. Simultaneous analysis of diazepam and its metabolites in rat plasma and brain tissue by HPLC-UV and SPE. Talanta 80, 279-285.

Milić, M., Divljaković, J., Rallapalli, S., van Linn, M.L., Timić, T., Cook, J.M., et al., 2012. The role of $\alpha 1$ and $\alpha 5$ subunitcontaining GABAA receptors in motor impairment induced by benzodiazepines in rats. Behav. Pharmacol. 23, 191-197.

Mirza, N.R., Larsen, J.S., Mathiasen, C., Jacobsen, T.A., Munro, G., Erichsen, H.K., et al., 2008. NS11394 [3'-[5-(1-hydroxy-1methyl-ethyl)-benzoimidazol-1-yl]-biphenyl-2-carbonitrile], a unique subtype-selective $\mathrm{GABA}_{\mathrm{A}}$ receptor positive allosteric modulator: in vitro actions, pharmacokinetic properties and in vivo anxiolytic efficacy. J. Pharmacol. Exp. Ther. 327, 954-968.

Munro, G., Lopez-Garcia, J.A., Rivera-Arconada, I., Erichsen, H.K., Nielsen, E.Ø., Larsen, J.S., et al., 2008. Comparison of the novel subtype-selective $\mathrm{GABA}_{\mathrm{A}}$ receptor-positive allosteric modulator NS11394 [3'-[5-(1-hydroxy-1-methyl-ethyl)benzoimidazol-1-yl]-biphenyl-2-carbonitrile] with diazepam, zolpidem, bretazenil, and gaboxadol in rat models of 
inflammatory and neuropathic pain. J. Pharmacol. Exp. Ther. 327, 969-981.

Munro, G., Ahring, P.K., Mirza, N.R., 2009. Developing analgesics by enhancing spinal inhibition after injury: $G_{A B A}$ receptor subtypes as novel targets. Trends. Pharmacol. Sci. 30, 453-459.

Nickolls, S., Mace, H., Fish, R., Edye, M., Gurrell, R., Ivarsson, M., et al., 2011. A comparison of the $\alpha 2 / 3 / 5$ selective positive allosteric modulators L-838, 417 and TPA023 in preclinical models of inflammatory and neuropathic pain. Adv. Pharmacol. Sci., 608912.

Olsen, R.W., Sieghart, W., 2008. International Union of Pharmacology. LXX. Subtypes of gamma-aminobutyric acid(A) receptors: classification on the basis of subunit composition, pharmacology, and function. Update Pharmacol. Rev. 60, 243-260.

Paul, J., Zeilhofer, H.U., Fritschy, J.M., 2012. Selective distribution of GABA(A) receptor subtypes in mouse spinal dorsal horn neurons and primary afferents. J. Comp. Neurol. 520, 3895-3911.

Popik, P., Kostakis, E., Krawczyk, M., Nowak, G., Szewczyk, B., Krieter, P., et al., 2006. The anxioselective agent 7-(2chloropyridin-4-yl)pyrazolo-[1,5-a]-pyrimidin-3-yl](pyridin-2-yl) methanone (DOV 51892) is more efficacious than diazepam at enhancing GABA-gated currents at alpha1 subunit-containing $\mathrm{GABA}_{\mathrm{A}}$ receptors. J. Pharmacol. Exp. Ther. 319, 1244-1252.

Prut, L., Belzung, C., 2003. The open field as a paradigm to measure the effects of drugs on anxiety-like behaviors: a review. Eur. J. Pharmacol. 463, 3-33.

Rabe, H., Kronbach, C., Rundfeldt, C., Lüddens, H., 2007. The novel anxiolytic ELB139 displays selectivity to recombinant GABA(A) receptors different from diazepam. Neuropharmacology 52, 796-801.

Ramerstorfer, J., Furtmüller, R., Vogel, E., Huck, S., Sieghart, W., 2010. The point mutation gamma 2F77I changes the potency and efficacy of benzodiazepine site ligands in different $\mathrm{GABA}_{\mathrm{A}}$ receptor subtypes. Eur. J. Pharmacol. 636, 18-27.

Read, K.D., Braggio, S., 2010. Assessing brain free fraction in early drug discovery. Expert. Opin. Drug Metab. Toxicol. 6, 337-344.

Rudolph, U., Möhler, H., 2006. GABA-based therapeutic approaches: $\mathrm{GABA}_{\mathrm{A}}$ receptor subtype functions. Curr. Opin. Pharmacol. 6, 18-23.

Rudolph, U., Knoflach, F., 2011. Beyond classical benzodiazepines: novel therapeutic potential of $\mathrm{GABA}_{\mathrm{A}}$ receptor subtypes. Nat. Rev. Drug Discov. 10, 685-697.

Savić, M.M., Milinković, M.M., Rallapalli, S., Clayton Sr., T., Joksimović, S., Van Linn, M., et al., 2009. The differential role of alpha1- and alpha5-containing GABA(A) receptors in mediating diazepam effects on spontaneous locomotor activity and water-maze learning and memory in rats. Int. J. Neuropsychopharmacol. 12, 1179-1193.

Savić, M.M., Majumder, S., Huang, S., Edwankar, R.V., Furtmüller, R., Joksimović, S., et al., 2010. Novel positive allosteric modulators of GABAA receptors: do subtle differences in activity at alpha1 plus alpha5 versus alpha2 plus alpha3 subunits account for dissimilarities in behavioral effects in rats?. Prog. Neuropsychopharmacol. Biol. Psychiatry 34, 376-386.

Sieghart, W., 2006. Structure, pharmacology, and function of $\mathrm{GABA}_{\mathrm{A}}$ receptor subtypes. Adv. Pharmacol. 54, 231-263.

Siemiatkowski, M., Sienkiewicz-Jarosz, H., Członkowska, A.I., Bidziński, A., Płaźnik, A., 2000. Effects of buspirone, diazepam, and zolpidem on open field behavior, and brain $\left[{ }^{3} \mathrm{H}\right]$ muscimol binding after buspirone pretreatment. Pharmacol. Biochem. Behav. 66, 645-651.

Skolnick, P., 2012. Anxioselective anxiolytics: on a quest for the Holy Grail. Trends Pharmacol. Sci. 33, 611-620.

Watanabe, M., Maemura, K., Kanbara, K., Tamayama, T., Hayasaki, H., 2002. GABA and GABA receptors in the central nervous system and other organs. Int. Rev. Cytol. 213, 1-47. 